\title{
An Investigation into the Effects of Martial Arts Training on Impulsive Consumer Behavior
}

\author{
Dimas Budi Prasetyo \\ Faculty of Psychology School of Psychology \\ Universitas Surabaya Bangor University
}

\author{
Paloma Mari-Beffa \\ School of Psychology \\ Bangor University
}

Consumer impulsiveness is an enticing topic regarding consumer behavior, and methods of avoiding such impulsiveness (through nurturing self-control) have been considered virtuous, mainly to achieve better long-term goals. Past studies show that self-control has been developed not only through a systematic theoretical framework but also neurologically. Martial arts (MA) training involves mind and body coordination, which is beneficial for nurturing concentration and self-control. The present study investigated the influence of martial arts training on individual capacity to avoid impulsive consumer behavior. Sixty-seven students joined in the study, in three different groups: (1) practitioners of martial arts (MA Group); (2) non-practitioners of martial arts (Non-MA Group); and (3) lapsed practitioner of martial arts (Lapsed-MA Group). The scale consisted of two separate subscales: (1) Consumer Impulsiveness Sub-scale (CIS); and (2) (Lack of) Premeditation Sub-scale. The study used some correlation methods, the ANCOVA method, and a hierarchical multiple linear regression analysis. Results showed that all three groups were prudent in their thinking processes and abilities to resist temptation. In the martial arts and ex-martial arts groups, the more frequent individual training (current training for the MA Group and in the past for the Lapsed MA Group), and the higher the ranks they achieved, significantly predicted their lower propensity towards impulsiveness in their consumer habits.

\section{Keywords: impulsive, self-control, martial arts, pre-meditation}

Keimpulsifan konsumen adalah topik menarik mengenai perilaku konsumen, dan metode untuk menghindari keimpulsifan (melalui pengembangan kontrol diri) telah dianggap baik, terutama untuk meraih tujuan jangka panjang yang lebih baik. Studi terdahulu menunjukkan bahwa kontrol diri telah dikembangkan tidak hanya melalui kerangka kerja teoretik sistematis namun juga secara neurologis. Pelatihan bela diri melibatkan koordinasi pikiran dan badan, yang berguna untuk mengembangkan konsentrasi dan kontrol diri. Studi ini menelusuri pengaruh dari latihan bela diri dalam kapasitas individu untuk menghindari perilaku impulsif konsumen. Studi ini melibatkan 67 siswa, dalam tiga kelompok berbeda: (1) praktisi bela diri (MA Group); (2) non-praktisi bela diri (Non-MA Group); dan (3) sudah lama bukan praktisi bela diri (LapsedMA Group). Skala terdiri dari dua sub-skala berbeda: (1) Consumer Impulsiveness Sub-scale (CIS); dan (2) (Lack of) Premeditation Sub-scale. Studi ini menggunakan sejumlah metode korelasi, analisis korelasi kovarians, dan analisis regresi linear jamak. Hasil menunjukkan bahwa ketiga kelompok memiliki kemampuan baik dalam proses berpikir dan kemampuan melawan godaan. Dalam MA Group dan Lapsed-MA Group, semakin sering latihan mandiri dilakukan (latihan yang sedang dilakukan untuk MA Group dan latihan di masa lalu untuk Lapsed MA Group), semakin tinggi tingkat yang diraih, memprediksi secara signifikan kecenderungan mereka yang lebih rendah atas keimpulsifan dalam kebiasaan berkonsumen.

Kata kunci: keimpulsifan, kontrol diri, bela diri, pre-meditasi

Impulsiveness and self-control do exist in the daily life of a consumer. Impulsiveness is considered profit-

Correspondence concerning this article should be addressed to Dimas Budi Prasetyo, Faculty of Psychology Universitas Surabaya. Jalan Raya Kali Rungkut, Surabaya 60293.E-mail: dimas.prasetyo@staff.ubaya.ac.id able by most 'fast-moving consumer goods' (FMCG) companies, and they have invested research efforts into how it might be used to maximize sales (Crawford \& Melewar, 2003). Indeed they, along with marketing researchers, have seen this impulsiveness as a power- 
ful tool, which can have a real influence on consumer purchasing behavior (Hausman, 2000). As an example of this may be seen in the context of a typical shopping day, consider this. A woman shopping on a tight budget, and who is on a diet, when passing by a shelf, filled with chocolate confectionary, suddenly stops and buys a chocolate bar, wrapped in attractive newlylaunched packaging. Here, good packaging is a striking sensory-emotional stimulus, which gives a pleasant feeling, despite the uncertainty of her not knowing the product. Consequently, she decides to follow her instincts to purchase the product without prudent thinking. The presence of self-control has been seen as virtuous in certain of its aspects (Casey, Somerville, Gotlib, Ayduk, Franklin, Askren, \& Glover, 2011; Duckworth and Seligman, 2005; Lieberman, 2013). Better self-control (which means lower impulsiveness) has been reported to affect increased income, and promote a happier life (Lieberman, 2013). The present study aims to investigate the factors contributing to better self-control in consumer habits.

Theoretically, impulsiveness occurs when an individual surrenders his or her capacity for self-control (Baumeister, 2002). Conversely, when self-control is higher, an individual may be better able to resist a particularly tempting stimulus. According to Hofmann, Friese, and Strack (2009), the fault of impulsive behavior frequently is related to an urge or approach towards a particular temptation. Usually, this temptation opposes the willpower to continue to strive for a longterm objective, and provides an immediate pleasurable reward; however, the ruin of an established long-term goal is the consequence (Puri, 1996). Baumeister (2002) further argued that impulsiveness is not a planned behavior, but spontaneous, when an immediate reward is available. An individual with high impulsiveness will ignore considering the consequences of the action, and follow the object/stimulus in front of him or her, which may give immediate pleasure (Hoch \& Loewenstein, 1991).

Lieberman (2013) further argued that self-control is a psychological construct, with the task of preventing any urge, impulse, or reaction, immediately to satisfy a temptation. Similarly, the final task of selfcontrol is to maintain individual's behavior on-thetrack; to keep it aimed at his or her established longterm goal, and its deterioration is a potential prelude to impulsiveness (Baumeister, 2002). The elicited responses of self-control may include thought (giving higher attention and focus to the goal), alteration of emotions (e.g., not being emotionally affected by any given situation), management of impulses (e.g., not being tempted towards immediate gratification), and the switching of performance (e.g., persisting towards a particular task). When an exam is held in the two days, a college student with a strong capacity for self-control will keep studying and resist buying and playing a newly-launched console game, even though it is something he or she has long awaited. Baumeister, Vohs, and Tice (2007) concluded that self-control reflects the ability of a person to modify his or her initial response to that normatively in line with ideals, morals, values, and social expectations, and to support the maintenance of long-term goals. The latter task is amongst the fundamentals, and is one of the emphasized areas, in the current research.

Hofmann et al. (2009) introduced the two constructs of impulsiveness and self-control in a dual-system model. The former is more immediate and spontaneous, while the latter is more a deliberative, cognitive process. Similarly, self-control is one of the virtues of System 2 in Kahneman's Two-Systems Theory (Kahneman, 2011). Self-control, he explained, has the task of controlling thoughts and behaviors, mainly when an individual is busy cognitively, which is when an impulsive decision is prone to be made (which is the default mode of how System 1 works). Impulsiveness is a condition suffered by people in the throes of a challenge from an effortful cognitive task, and, therefore, to whom immediate temptation seems to be very attractive (Kahneman, 2011).

Self-control also relates to ego depletion - a term coined by Baumeister, Bratslavsky, Muraven, and Tice (1998) in which one's ability to resist any temptation might be decreased after he/she has done similar exertion before. In this premise, one's ability of exerting selfcontrol will depend on the resources (similar to certain form of strength or energy) and therefore, if succeeded to resist on one occasion (which takes certain amount of resource), then the subsequent resistance will be less likely to occur because the amount of resource is reduced (Baumeister et al., 1998; Hofmann et al., 2009; Vohs et al., 2008). Past studies which were conducted by Baumeister et al. (1998) and Baumeister and Tierney (2011) could be an example for this, where they found a different response to task performing in two different group conditions. Beforehand, the first group was allowed to eat delicious freshly-baked cookies when they were given a choice to pick either eating cookies or radishes. The second group was assigned similar options but prompted to eat the radish. The two groups were then asked to solve an unsolved puzzle problem. The first group was able to stay with the problem longer than the second group. 
The finding suggests that one's exertion of resources to resist eating cookies decreased the subsequent ability to resist the temptation to quit the game early.

Self-control is essential, as Duckworth and Seligman (2005) argued, it is associated with getting a higher Grade Point Average (GPA) in college. Greater selfcontrol, Lieberman (2013) further stated, is associated with a higher income, higher credit scores, better health, better social skills from childhood to adulthood, and greater reported happiness with life. He further argued that self-control is like a 'brake', and, neurologically, takes place in the human frontal cortex, that is the right-ventro lateral prefrontal cortex (rVLPFC). Interestingly, this region does not develop until late adolescence, a period in which one's self-control skill evolves substantially. This result is consistent with the past study (Aron, Robbins, \& Poldrack, 2004), showing increased activity in this region of the brain, activated when an individual under observation was successful in not pressing the buttons of no-go trials, in go/no-go tasks. Similarly, in a longitudinal study, Casey et al. (2011) found that their four-year-old participants, who were reported as being better in delaying gratification, simi-larly produced increased activity in their rVLPFCs, when they were re-tested four decades later in their adulthood. Though results are still inconclusive, as to how the rVLPFC functions as a 'braking system' (Lieberman, 2013), previous studies (Baumeister, Bratslavsky, Muraven, \& Tice, 1998; Vohs \& Heatherton, 2000) suggested that this 'breaking' system is like a muscle, which needs exercise to strengthen its function.

One of the ways to strengthen the capacity for self-control is through repeated exercise (Muraven, Baumeister, \& Tice, 1999), and martial arts being one of the forms of this. According to Woodward (2009), martial arts facilitate attentiveness and reduce impulsiveness among students by having them adhere to visual and verbal instruction and focus deeply on physical activity in a disciplined and controlled environment; thus promoting concentration and selfcontrol, simultaneously. Additionally, previous studies postulated that a study of martial arts is beneficial for developing early self-control in children (Diamond \& Lee, 2011, Lakes \& Hoyt, 2004; Woodward, 2009), and later at the adult stage (Banks et al., 2014; Sánchez-López, Fernández, Silva-Pereyra, \& Mesa, 2013). Finally, Sánchez-López et al., (2013) revealed that particular types of martial arts which involve meditation (e.g., kung-fu, aikido, etc.) are proven to enhance capacity for self-control and emotional control. The latter fact, they further argued, was neuro- logically proven, and evidenced by increased activity in the prefrontal cortex and anterior cingulate cortex, the areas known to be involved in self-control.

Muraven et al. (1999) further argued that, even if people practice martial arts, they will not necessarily gain any direct effect, unless they commit to, and frequently attend training. Likewise, exercise can often further benefit them in attaining a certain level of mastery (King \& Williams, 2008). Thus, the length and frequency of training, as well as the level of mastery (the effect of longer training) may contribute to the development of self-control. Moreover, being physically active and having bad habits also contribute to the impulsiveness of people, as suggested by Calfas and Taylor (1994), who stated that being active in some physical way is positively linked to self-esteem and good self-concept, and negatively linked to depressive symptoms and anxiety/stress. Similarly, a specific type of lifestyle may be a significant inhibitor of self-control; such as high alcohol consumption, whereby alcohol drinkers are among the high-risk group for being more impulsive than non-drinkers (Noël et al., 2007).

The present study aimed to predict and characterize the tendency to behave impulsively in the consumer context (or to exert self-control and to maintain any established better long-term goal) through engagement in, and commitment to, martial arts training. The study utilized martial arts training as a tool to achieve better self-control. The martial arts involved in the study were more aligned to traditional martial arts (karate, aikido, etc.), which King and Williams (2008) explained had the benefit of allowing an individual to focus on how to achieve self-improvement, effort and task-mastery, to grow. Traditional martial arts seems to be more beneficial for maintaining long-term goals, as it allows the individual to train to a certain level of mastering techniques. Martial arts have been reported as bringing many benefits to human life (Diamond \& Lee, 2001; Woodward, 2009). This article has shown its role as one of the variables being responsible for the maintenance of self-control (Muraven et al., 1999) - hence it is possible it may be one of the predictors of impulsive behavior by the consumer.

This research investigated three different groups in which impulsive consumer behavior might be likely to occur. The first group consisted of those who currently participated, and actively engaged, in any martial arts training (the martial arts, or MA Group). The next one comprised those who had never participated in any martial arts training (non-martial 
arts or Non-MA Group). The last involved those who had trained in martial arts sometime in the past but had ceased training (Lapsed MA Group). The present study has three hypotheses. The first one would test whether the three situations of the groups might differ in terms of impulsiveness. Specifically, an individual in the MA group might have shown lower impulsiveness, compared to the other two groups. Second hypotheses would answer whether continuously training in martial arts might have provided a person with lower impulsiveness (consistent with Lakes \& Hoyt, 2004; Muraven et al., 1999; Sánchez-López et al., 2013; Woodward, 2009). The critical question was whether this lower impulsiveness would last, even if the person stopped training (this is the third hypotheses).

\section{Method}

The study employed eighty-one participants (Psychology student at Bangor University, Wales, United Kingdom), in which 14 of them were removed due to their leaving some questions blank. After the ethical basis for the study was approved, it was advertised in the SONA system (the Bangor University student panel system) then Bangor University Psychology students were recruited through the SONA system. One SONA credit was granted when participation in the study was completed. The research ethics committee approved the study at Bangor University. Only those who had provided their consent for the study were recruited as participants. The study used a betweengroup design using 67 participants.

The scales, consisting of some demographic questions, and two separate sub-scales, were adjusted. These were the Consumer Impulsiveness Scale (CIS) (Puri, 1996) and the Premeditation sub-scale from the Urgency, Premeditation, Perseverance, Sensation Seeking (UPPS) impulsive behavior scale (Whiteside \& Lynam, 2001). The Consumer Impulsiveness Scale contains a set of short and straightforward statements, directly related to the context of consumer impulsiveness (Puri, 1996). The UPPS sub-scale (Whiteside \& Lynam, 2001) was developed as a derivation of four personality factors, intended to predict the impulsive personality: premeditation, sensation seeking, urgency, and perseverance. The current research used only the premeditation subscale, owing to its higher relatedness to other described constructs, and its relevance to consumer behavior. Premeditation itself is the propensity of an individual to think, consider and reflect on the possible outcomes which might occur as a result of his or her intended behavior, before performing that behavior (Whiteside \& Lynam, 2001). It is nearly identical to the function of self-control in System 2 of Kahneman's Two Systems Theory (Kahneman, 2011), wherein he described it as comprising the cautious, deliberative, comparative, and effortful mental activities which require concentration and reasoning.

Table 1

Participants Demographic Data

\begin{tabular}{|c|c|c|c|c|c|c|c|c|c|c|c|}
\hline & \multicolumn{3}{|c|}{ MA } & \multicolumn{3}{|c|}{ Non-MA } & \multicolumn{3}{|c|}{ Lapsed MA } & \multirow[b]{2}{*}{$F$} & \multirow[b]{2}{*}{$p$} \\
\hline & $N$ & $M$ & $S D$ & $N$ & $M$ & $S D$ & $N$ & $M$ & $S D$ & & \\
\hline Age (years) & 22 & 27.98 & 9.33 & 22 & 22.63 & 5.10 & 23 & 26.89 & 8.28 & 9.93 & $<.001$ \\
\hline BMI* & 18 & 18.76 & 9.53 & 17 & 18.02 & 9.59 & 21 & 21.56 & 7.61 & 1.81 & .166 \\
\hline $\begin{array}{l}\text { Alcohol Consumption** } \\
\text { Number of Martial Arts }\end{array}$ & 22 & 7.90 & 8.20 & 22 & 5.01 & 7.74 & 19 & 3.63 & 4.07 & 7.00 & .001 \\
\hline Students who Participated & 22 & 2.08 & 1.55 & - & - & - & 23 & 1.37 & 0.95 & 12.22 & .001 \\
\hline Length of Training (years) & 22 & 8.33 & 6.26 & - & - & - & 23 & 4.91 & 6.95 & 10.48 & .001 \\
\hline $\begin{array}{l}\text { Frequency of Training } \\
\text { (per week) } \\
\text { Level of Mastery (in }\end{array}$ & 22 & 2.11 & 1.32 & - & - & - & 23 & 1.67 & 1.01 & 5.70 & .018 \\
\hline belt/rank)*** & 22 & 2.17 & 0.74 & - & - & - & 23 & 1.64 & 0.65 & 23.14 & $<.001$ \\
\hline Number of Activities & 22 & 2.66 & 2.05 & 22 & 2.07 & 1.84 & 23 & 2.89 & 1.88 & 3.72 & .026 \\
\hline
\end{tabular}

Note. *Body Mass Index: an index derived from a person's weight in kilograms divided by the square of height in meters. ** The calculation is based on the quantity of pure alcohol in a drink (one unit) consumed in a week. For example, $10 \mathrm{ml}$ or $8 \mathrm{~g}$ of pure alcohol is considered as 1 unit. People are advised not to exceed 14 alcohol units per week. Please refer towww.nhs.uk/live-well/alcohol-support/calculating-alcohol-units/. *** The number was classified based on the rank that the participant has achieved. 1 indicates lower rank (e.g. white belt in Judo, orange belt in Shotokan, beginner level in Wing Chun, etc.); 2 represents intermediate rank (e.g. 3rd kyu in Aikido, red belt in Tae Kwon Do, etc.); 3 indicates higher/advanced rank (mostly blackbelt holders). The classification was made based on expert/practitioner judgement. 
All sub-scales were adapted to a seven-point Likerttype format. Three items in the CIS sub-scale were deleted, owing to their values being below 0.3 , measured using corrected item-total correlation (final $\alpha$ $=.872$, with nine items in total), while the item number of the Premeditation sub-scale remained as it was (no value below $0.3, \alpha=.891$ ). The study further correlated between the two sub-scales and elicited a positive correlation $(r=.75, p<.001)$, supporting the contention that the two sub-scales indeed measured similar variables. The total number of items used after measuring their internal consistency was 16 , along with generic demographic variable items (age, alcohol usage, BMI, number of activities-result shown in Table 1), and MA-related variable items (the number of martial arts in which participants were engaged, the frequency of training, the time length of training, the level of mastery). After data collection, all the items and scores were aligned, so that they all had similar meanings when analyzing the response interpretation. A higher score indicates an individual with a higher propensity for being impulsive, and someone less deliberative, while a lower score signifies his or her tendency towards being more self-controlled and prudently deliberative.

The study used the Statistical Package for Social Science (SPSS) for data processing with these statistical tools: (1) Pearson product moment correlation; (2) a one-way ANCOVA (Analysis of Covariance); and (3) a hierarchical forward multiple regression. The first stage of analysis included on the correlation between the overall mean score and the generic variables. Then an ANCOVA was completed, to check any group effect which caused any differences in the group, after controlling any generic variables which might correlate with the overall means score. Lastly, the analysis went on to check any correlation between the total score and the MA-related variables, in both the MA Group and the Lapsed MA Group. All of this was conducted at the sub-scale level. Finally, hierarchical forward multiple regression analysis was conducted, to yield a model consisting of factors which might contribute to impulsive consumer behavior in the MA and Lapsed MA groups.

\section{Results}

\section{Consumer Impulsiveness Scale}

A bivariate correlation between the CIS mean score and the generic variables yielded positive corre- lations between the CIS mean score and alcohol consumption $(r=.30, p<.001)$, and a negative correlation between the CIS mean score and age $(r$ $=-.23, p=.002)$, BMI $(r=-.26, p<.001)$, and number of activities $(r=-.17, p=.016)$. A one-way ANCOVA was then conducted to determine the differences of the CIS scores amongst the three groups, controlling age, Body Mass Index (BMI), number of activities, and alcohol consumption. However, there was no significant effect from group classification, on the CIS score, after controlling these variables $\left(F(2,183)=0.05, p=.948, \eta^{2} P=.00\right)$. Therefore, the first hypothesis was rejected. Further correlation analyses were conducted between the CIS mean score and the MA-related variables, in both MA and Lapsed MA groups. Results showed a significant correlation in the MA Group, between the CIS mean scores and number of martial arts in which the participants were active $(r=-.29, p=.011)$, the number of years they had engaged in the training $(r$ $=-.35, p=.002)$, the frequency of the training $(r=$ $-.60, p<.001)$, and the level of mastery $(r=-.26, p$ $=.022)$. In the Lapsed MA Group, similar significance was also evident in correlations between the CIS mean score, the frequency of training $(r=-.28, p$ $=.013)$, and the level of mastery $(r=-.25, p=.026)$.

\section{UPPS - Premeditation}

A bivariate correlation was done to identify any significant correlation between the scores and the general variables. Two of these had a significant correlation (negative) with the premeditation sub-scale, i.e., the number of activities $(r=-.17, p=.020)$ and alcohol consumption $(r=-.26, p<.001)$. However, no significant effect of group situation on premeditation scores was evident, even after controlling the covariate $\left(F(2,219)=0.91, p=.406, \eta^{2} P=.01\right)$ as a result of a one-way ANCOVA (controlling the effect of the number of activities and alcohol consumption). The results further confirm the rejection of the first hypotheses. Additionally, a bivariate correlation was further computed, to check any relationship, specifically between the mean score and MA-related variables in both the MA and the Lapsed MA groups. Results showed no significant correlation in the MA Group, but in the Lapsed MA Group there were three significant negative correlations between the scores and the number of martial arts in which participants engaged $(r=-.22, p=.047)$, the frequency of training $(r=-.28, p=.012)$, and the level of mastery $(r=-.22$, $p=.048)$. 


\section{Predicting Consumer Impulsiveness From Martial Arts Training Variables}

Finally, hierarchical forward multiple regression analysis was conducted to predict the impact of martial training experience on consumer impulsiveness, with the CIS score as the dependent variable. This analysis was done for both the MA Group (see Table 2) and the Lapsed MA Group (see Table 3). In the MA Group, three variables were accepted in the equation in Step 1, showing alcohol consumption as the best predictor, followed by age and number of activities, while BMI was excluded. All MA-related variables were included in Step 2. The final model was statistically significant $\left(R^{2}=.79, F(7,69)=37.17\right.$, $p<.001$ ), accounted for approximately $79 \%$ of the variance of consumer impulsiveness in the MA Group. However, the number of activities, the number of MA participants, and time length of training were not significant predictors for consumer impulsiveness. Standardized beta ( $\beta$ ) weights for alcohol consumption $(\beta=.70, p<.001)$ was higher than age $(\beta=-$ $.40, p<.001)$, frequency of training $(\beta=-.35, p$ $<.001)$ and level of mastery $(\beta=-.31, p<.001)$.

In the Lapsed MA Group, all demographic variables (age, BMI, alcohol consumption, number of activities) were not significant predictors. The model was statistically significant $\left(R^{2}=.24, F(4,61)=4.88, p\right.$ $=.002)$, accounted for approximately $24 \%$ of the variance of consumer impulsiveness in the Lapsed MA Group. However, years participating in MA were an insignificant predictor for consumer impulsiveness. Standardized beta $(\beta)$ weights for the number of MA in which they participated $(\beta=.76, p$ $=.010)$ were higher than frequency of training $(\beta=-$ $.72, p=.004)$ and level of mastery $(\beta=-.30, p=.034)$.

\section{Discussion}

The present study investigated whether martial arts could help shape individual self-control and resist impulsive consumer behavior. In general, the first hypothesis was rejected (no significant difference in impulsiveness across the three groups). However, training in martial arts did indeed predict better selfcontrol, and lower impulsiveness, in consumer behavior, and this even benefited those who had lapsed in their practice. Thus, the second and third hypotheses were accepted.

The analysis in the CIS sub-scale showed no significant differences across the three groups, nor in the

Table 2

Hierarchical Forward Multiple Regression Result Showing Predictors of Impulsive Consumer Behavior (CIS score as the dependent variable) in the MA Group

\begin{tabular}{|c|c|c|c|c|c|c|}
\hline & \multirow{2}{*}{ Predictor } & \multirow[b]{2}{*}{$R^{2}$} & \multirow[b]{2}{*}{$R^{2}$ change } & \multicolumn{3}{|c|}{ Impulsive Consumer Behavior } \\
\hline & & & & $F$ & $F$ change & $\beta$ \\
\hline \multirow[t]{2}{*}{ Model 1} & & .19 & .19 & $17.31 * * *$ & $17.31 * * *$ & \\
\hline & Age & & & & & $-.43 * * *$ \\
\hline \multirow[t]{3}{*}{ Model 2} & & .49 & .30 & $35.25 * * *$ & $43.45^{* * * *}$ & \\
\hline & Age & & & & & $-.58 * * *$ \\
\hline & Alcohol consumption & & & & & $.57 * * *$ \\
\hline \multirow[t]{4}{*}{ Model 3} & & .51 & .03 & $25.92 * * *$ & $4.21 *$ & \\
\hline & Age & & & & & $-.53 * * *$ \\
\hline & Alcohol consumption & & & & & $.58 * * *$ \\
\hline & Number of activities & & & & & $-.18 *$ \\
\hline \multirow[t]{8}{*}{ Model 4} & & .79 & .28 & $37.17 * * *$ & $22.67 * * *$ & \\
\hline & Age & & & & & $-.40 * * *$ \\
\hline & Alcohol consumption & & & & & $.70 * * *$ \\
\hline & Number of activities & & & & & -.01 \\
\hline & Number of martial arts undertaken & & & & & -.07 \\
\hline & Length of training & & & & & -.06 \\
\hline & Frequency of training & & & & & $-.35 * * *$ \\
\hline & Level of mastery & & & & & $-.31 * * *$ \\
\hline
\end{tabular}




\section{Table 3}

Hierarchical Forward Multiple Regression Results, Showing Predictors Of Impulsive Consumer Behavior (CIS score as the dependent variable) in the Lapsed MA Group

\begin{tabular}{|c|c|c|c|c|c|}
\hline \multirow{2}{*}{ Predictor } & \multirow[b]{2}{*}{$R^{2}$} & \multirow[b]{2}{*}{$R^{2}$ change } & \multicolumn{3}{|c|}{ Impulsive Consumer Behavior } \\
\hline & & & $F$ & $F$ change & $\beta$ \\
\hline Model 1 & .24 & .24 & $4.88 * *$ & $4.88 * *$ & \\
\hline Number of martial arts undertaken & & & & & $.76^{*}$ \\
\hline Length of training & & & & & -.30 \\
\hline Frequency of training & & & & & $-.72 * *$ \\
\hline Level of mastery & & & & & $-.30 *$ \\
\hline
\end{tabular}

premeditation sub-scale, even after controlling the demographic variables which positively correlated (covariates) with the scale. Analysis done at the CIS scale level shows a positive correlation between the CIS score and alcohol consumption $(r=.30, p<.001)$ and a negative correlation between the CIS score and the number of activities undertaken $(r=-.17, p$ $=.016)$. The finding is consistent with the previous study (Noël et al., 2007), in which excessive drinking habits characterize that impulsive person, whilst undertaking various activities may be associated with having a more nurtured self-control (analysis done at the premeditation scale level also confirmed the latter finding, $r=-.17, p=.020)$. This result also means that the bustle of their activity influenced their propensity to think and act more thoroughly. Therefore, the results contribute to the previous study (Calfas \& Taylor, 1994) in which being active might be beneficial for developing higher self-control. However, this study seems, at a glance, to be at variance with the first and second research hypotheses, wherein there was a difference in impulsiveness between people with MA experience (both the MA Group and the Lapsed MA group) and non-MA people, and where individuals with the former characteristics were those having more capability for self-control than the latter group. Though the results show a similar tendency to impulsiveness across the group, all groups were considered somewhat able to control themselves, in the face of tempting stimuli. On average, they scored 3 out of 7, across the groups, i.e., the MA Group $(N=22, M=3.26, S D=1.20)$, the Non-MA Group $(N=22, M=3.12, S D=.81)$, and the Lapsed MA group $(N=23, M=3.10, S D=.91)$; the higher they scored, the greater their tendency to act on the spur of the moment and without careful planning. Therefore, all groups had a similar level of self-control, including the MA Group. This finding confirms the consistent results done at the premeditation scale level battery (in which there was no dif- ference across the groups, all falling within a similar range of self-control capacity). Particularly in the MA Group, the low level of impulsiveness may have been stimulated by their activities in martial arts training (that is in MA-related variables).

Through regression analysis, the present study elicited a model which might help explain the road to developing higher self-control in consumer behavior. With a great effect size in the MA Group $\left(R^{2}=.79\right)$, the model suggested that higher alcohol consumption was the best predictor of impulsiveness, and this was followed by a younger age. Interestingly, MA variables were amongst the predictors: infrequent attendance at training, and lower achievement/mastery (in belt/rank). The elicited model was consistent with a past study, where alcohol was one of the predictors for impulsiveness (Noël et al., 2007). Moreover, the correlation analysis, between the CIS mean score - alcohol consumption and CIS mean score - age confirmed that higher use of alcohol $(r=.30, p<.001)$ and the younger generation $(r=-.23, p=.002)$ was associated with a greater proneness to impulsiveness. Further analysis in the MA Group also confirmed that infrequent attendance at training and a lower level of mastery correlated with impulsiveness (higher CIS score). Thus, the model established the martial arts ability to develop better self-control, particularly in consumer behavior and purchasing decisions, but this should be followed by efforts by individuals to reduce their alcohol consumption and increase the time spent at regular training, to achieve higher levels of mastery/ belts. Being consistent with previous studies showing martial arts capability to nurture self-control (Banks et al., 2014; Diamond \& Lee, 2011; Lakes \& Hoyt, 2004; Muraven et al., 1999; Sánchez-López et al., 2013; Woodward, 2009), the model confirms the third hypothesis, where martial arts contributes towards practitioner likelihood of developing ability for self-control. 
Another regression analysis was performed, to check whether the effect of the development of higher self-control could be of benefit, even for those who had ceased training (Lapsed MA group). Unlike in the MA Group, the model generated from this group had a lower effect size (about one-fourth of the overall variability of the Lapsed MA Group recorded responses). The model suggested that someone who stopped training may be prone to have higher impulsiveness if: he or she was not focused on training in one type of martial art in the past; rarely came to training sessions, and thus did not progress to higher belts/levels/mastery. This finding was confirmed further through correlation analysis, showing a correlation between being more prudent (lower premeditation score) more persistent (lower CIS score) and having a higher level of mastery (e.g., brown belt in aikido) in the Lapsed MA Group. Moreover, a similar correlation occurred between being prudent (lower CIS score) and regular training. Thus, consistent with previous findings, it seems that in martial arts, the frequency of training and the pursuit of higher levels of mastery (belt/rank) are the keys to nurturing self-control. This finding confirmed those of two previous studies. Firstly, regular training may be associated with the repeated exercise that Muraven et al. (1999) suggested was useful to train the 'muscle' of self-control. Secondly, achieving higher levels of mastery, as argued by King and Williams (2008), is advantageous, not only to encourage self-improvement, effort and task mastery but also to train the 'muscle' of self-control, by maintaining regular training for better long-term goals (higher degree belts) and to resist the temptation to abandon such practice. Therefore the current study gives an initial indication that the effect of a 'trainedmuscle' for self-control may be of benefit, even for those who have abandoned earlier training.

Some limitations to the current research are related to the low number of participants (the current study used only 20-24 participants in each classification) and its less diverse participant characteristics who were mostly British while only a few were international students and a few from universities across the UK). Using a wider range of participants would enhance the diversity of the demographic, hence increasing the universality of the findings. Finally, the current study used only a standard measurement of self-reporting techniques. Self-reporting has its weaknesses, eliciting biased responses, based on individual claims. A more advanced method, using experimental tools such as go/no-go tasks (computerized tests used to assess inhibitory control, a cognitive process which enables humans rapidly to inhibit motor activity even after its initiation) and more advanced tools such as an Electroencephalogram (EEG) or functional Magnetic Resonance Imaging (fMRI) would be beneficial, precisely to record the true responses from participants, and these might be used to support the results of selfreporting, by showing the activity in a particular brain area which functions as a "braking system" (Lieberman, 2013). Further study should involve different types of repeated exercise, a routine training incorporating power and stamina (Muraven et al., 1999), separately and using the results as independent variables.

Future study on impulsive consumer behavior needs to develop firmer measurement scales and to address and select factors which truly represent impulsiveness in consumer behavior. Eventually, integrated measurement tools should be used, involving both self-reporting questionnaires and a laboratory-based experimental inventory. These could be some of the options suitable to address the probability of biased responses obtained from self-reporting questionnaires only. Finally, the study showed additional benefits from the practice of martial arts. Such practice could be one of the methods considered to shape individual self-control, resist any immediate temptation, and to look for a better reaction. Impulsiveness is quite problematic in consumer life. Participating and continuously training in martial arts could be a way to exercise the 'muscle' of self-control, and resist the ego depletion of the individual. In other words, martial arts training may promote the tendency of people to purchase only the things they need (relevant to their better long-term goals), to become smart shoppers and to improving consumer behavior.

The abstract of this paper was presented on The 4th International Conference on Education, Psychology, and Social Sciences (2018 ICEPS), July 10-12, 2018 in Tokyo, Japan.

\section{References}

Aron, A. R., Robbins, T. W., \& Poldrack, R. A. (2004). Inhibition and the right inferior frontal cortex. Trends in Cognitive Sciences, 8(4), 170177. https://doi.org/10.1016/j.tics.2004.02.010

Banks, S. J., Mayer, B., Obuchowski, N., Shin, W., Lowe, M., Phillips, M., ... \& Bernick, C. (2014). Impulsiveness in professional fighters. The Journal of Neuropsychiatry and Clinical Neurosciences, 26(1), 44-50. https://doi.org/10.1176/appi.neuropsych. 


\section{5}

Baumeister, R. F. (2002). Yielding to temptation: Self-control failure, impulsive purchasing, and consumer behaviour. Journal of Consumer Research, 28(4), 670-676. https://doi.org/10.1086/338209

Baumeister, R. F., Bratslavsky, E., Muraven, M., \& Tice, D. M. (1998). Ego depletion: Is the active self a limited resource? Journal of Personality and Social Psychology, 74(5), 1252-1265. https://doi.org/10.10 37/0022-3514.74.5.1252

Baumeister, R. F., \& Tierney, J. (2011). Willpower: Why self-control is the secret to success. England: Penguin Books.

Baumeister, R. F., Vohs, K. D., \& Tice, D. M. (2007). The strength model of self-control. Current Direction in Psychological Science, 16(6), 351-355. https:// doi.org/10.1111/j.1467-8721.2007.00534.x

Calfas, K. J., \& Taylor, W. C. (1994). Effects of physical activity on psychological variables in adolescents. Pediatric Exercise Science, 6(4), 406423. https://doi.org/10.1123/pes.6.4.406

Casey, B. J., Somerville, L. H., Gotlib, I. H., Ayduk, O., Franklin, N. T., Askren, M. K., ... \& Glover, G. (2011). Behavioral and neural correlates of delay of gratification, 40 years later. Proceedings of the National Academy of Sciences, 108(36), 1499815003. https://doi.org/10.1073/pnas.1108561108

Crawford, G., \& Melewar, T. C. (2003). The importance of impulse purchasing behaviour in the international airport environment. Journal of Consumer Behaviour, 3(1), 85-98. https://doi.org/ 10.1002/cb.124

Diamond, A., \& Lee, K. (2011). Interventions shown to aid executive function development in children 4-12 years old. National Institute of Health, 333(6045), 959-964. https://doi.org/10.1126/science.1204529

Duckworth, A. L., \& Seligman, M. E. (2005). Selfdiscipline outdoes IQ in predicting academic performance of adolescents. Psychological Science, 16(12), 939-944. https://doi.org/10.1111/j.1467-92 8.2005.01641.x

Hausman, A. (2000). A multi-method investigation of consumer motivations in impulse buying behavior. Journal of Consumer Marketing, 17(5), 403-426. https://doi.org/10.1108/07363760010341045

Hoch, S. J., \& Loewenstein, G. F. (1991). Timeinconsistent preferences and consumer self-control. Journal of Consumer Research, 17(4), 492-507. https://doi.org/10.1086/208573

Hofmann, W., Friese, M., \& Strack, F. (2009). Impulse and self-control from a dual-systems perspective. Perspectives on Psychological Science, 4(2), 162-176. https://doi.org/10.1111/j.1745-6924.2009.01116.x

Kahneman, D. (2011). Thinking fast and slow. Great Britain: Penguin Books.

King, L. A., \& Williams, T. A. (2008). Goal orientation and performance in martial arts. Journal of Sport Behavior, 20(4), 397-411. Retrieved from https:// search.proquest.com/docview/1311950515/fullte xt/E0F800CF47064F20PQ/1 ?accountid=14874

Lakes, K. D., \& Hoyt, W. T. (2004). Promoting selfregulation through school-based martial arts training. Applied Developmental Psychology, 25(3), 283-302. https://doi.org/10.1016/j.appdev.2004.04.0 02

Lieberman, M. D. (2013). Social: Why our brains are wired to connect. United States: Broadway Books.

Muraven, M., Baumeister, R. F., \& Tice, D. M. (1999). Longitudinal improvement of self-regulation through practice: Building self-control strength through repeated exercise. The Journal of Social Psychology, 139(4), 446-457. https://doi.org/10.1080/002245 49909598404

Noël, X., Van der Linden, M., d'Acremont, M., Bechara, A., Dan, B., Hanak, C., \& Verbanck, P. (2007). Alcohol cues increase cognitive impulsiveness in individuals with alcoholism. Psychopharmacology, 192(2), 291-298. https://doi.org/10.1007/s00213006-0695-6

Puri, R. (1996). Measuring and modifying consumer impulsiveness: a cost-benefit accessibility framework. Journal of Consumer Psychology, 5(2), 87-113. https://doi.org/10.1207/s15327663jcp0502_01

Sánchez-López, J., Fernández, T., Silva-Pereyra, J., \& Mesa, J. A. M. (2013). Differences between judo, taekwondo and kung-fu athletes in sustained attention and impulse control. Psychology, 4(07), 607-612. https://doi.org/10.4236/psych.2013.47086

Vohs, K. D., Baumeister, R. F., Schmeichel, B. J., Twenge, J. M., Nelson, N. M., \& Tice, D. M. (2008). Making choices impairs subsequent selfcontrol: a limited resources account of decision making, self-regulation, and active initiative. Journal of Personality and Social Psychology, 94(5), 883898. https://doi.org/10.1037/0022-3514.94.5.883

Vohs, K. D., \& Heatherton, T. F. (2000). Selfregulatory failure: A resource-depletion approach. Psychological Science, 11(3), 249-254. https://doi. org/10.1111/1467-9280.00250

Whiteside, S. P., \& Lynam, D. R. (2001). The five factor model and impulsiveness: Using a structural model of personality to understand impulsiveness. Personality and Individual Differences, 30(4), 669689. https://doi.org/10.1016/s0191-8869(00)00064-7 Woodward, T. W. (2009). A review of the effects of 
martial arts practice on health. Wisconsin Medical Journal, 108(1), 40-43. Retrieved from http://www.
wisconsinmedicalsociety.org/_WMS/publications /wmj/pdf/108/1/40.pdf 